DOI:

\title{
Penerapan Penilaian Persediaan Dan Perhitungan Harga Pokok Makanan Dengan Metode Fifo Pada Aplikasi Berbasis Web
}

\author{
Gabriella Dwi Ayuni ${ }^{1}$, Magdalena Karismariyanti ${ }^{2}$ \\ Program Studi D3 Komputerisasi Akuntansi, Fakultas Ilmu Terapan Universitas Telkom \\ Email: ${ }^{1}$ ayuella812@gmail.com, ${ }^{2}$ magdalena@tass.telkomuniversity.ac.id
}

\section{Keywords:}

cost of food, FIFO, web, foodservice

\section{Kata Kunci:}

harga pokok makanan, FIFO, web, restoran

\section{Abstract}

The cost of food involved food consumed whereas labor costs and overhead costs were excluded. Both excluded costs were charged to various department. The value of the cost-of-food-sold shown in the food cost report, can be used as a reference to improve operational efficiency and take corrective actions. The value of the cost of foods consumed can be directly obtained from the inventory card using the First In First Out (FIFO) Method. The FIFO method calculated the actual cost of goods from the value of the goods themselves. In a foodservice industry, control of food supplies was an important activity, because inventory is one of the current assets nonetheless it is perishable. Moreover, inventory related transactions that had buge volume daily recorded unsystematically, can cause trouble with different amount between physical inventory checking and reports. Based on the weaknesses of the recording process, document flow analysis was carried out. Document flow analysis was used as a reference for developing web-based applications. This application was able to handle purchasing, delivery of food items from the purchasing department to the kitchen section, pick up of food ingredients for kitchen/ meeting/promotion purposes, physical adjustment of inventory and displaying inventory cards and cost of food report.

\section{Abstrak}

Harga pokok makanan melibatkan biaya penggunaan bahan makanan tanpa melibatkan biaya tenaga kerja dan biaya overhead. Kedua biaya tersebut dibebankan pada setiap departemen. Nilai pada harga pokok makanan yang dijual ditampilkan di laporan harga pokok makanan, yang dapat digunakan sebagai acuan untuk meningkatkan efisiensi operasional dan melakukan tindakan koreksi. Nilai pada Harga Pokok Makanan yang dikonsumsi dapat secara langsung diperoleh dari kartu persediaan dengan Metode First In First Out (FIFO). Metode FIFO menghitung harga perolehan barang yang sesunggubnya dari nilai dari barang itu sendiri. Pada jenis usaha restoran, pengawasan persediaan bahan makanan menjadi kegiatan penting, karena persediaan merupakan salah satu harta lancar namun mudah rusak. Selain itu, Transaksi terkait persediaan, yang memiliki volume sangat besar setiap hari, dicatat secara tidak sistematis dapat mengakibatkan masalah ketidaksesuaian jumlah antara pemeriksaan fisik persediaan dengan catatan. Berdasarkan kelemahan proses pencatatan, dilakukan analisis aliran dokumen. Analisis aliran dokumen dijadikan acuan untuk membangun aplikasi berbasis web. Aplikasi ini mampu menangani pembelian, penyerahan bahan makanan dari bagian pembelian ke bagian dapur, pengambilan bahan makanan untuk keperluan dapur/rapat/promosi, penyesuaian fisik persediaan dan menampilkan kartu persediaan dan laporan harga pokok makanan. 


\section{Pendahuluan}

Kongkalikong Dine and Cafe memiliki 317 bahan makanan yang akan digunakan dalam pembuatan 70 menu yang tersedia. Tempat penyimpanan bahan makanan terdiri dari dua tempat yaitu penyimpanan bagian pembelian dan penyimpanan bagian dapur. Pencatatan persediaan bahan makanan dilakukan pada kedua tempat penyimpanan. Pengawasan persediaan bahan makanan dilakukan oleh bagian pembelian. Mengingat bahan makanan termasuk barang mudah rusak, dilakukan pembelian per hari[1]. Pencatatan persediaan bagian pembelian menggunakan program Microsoft Excel namun pencatatan bagian dapur masih menggunakan catatan persediaan berbasis kertas. Pencatatan pengambilan dan perhitungan persediaan akhir pada bagian dapur masih tidak teratur. Hal tersebut menyebabkan jumlah persediaan bahan makanan pada buku catatan tidak sesuai dengan jumlah persediaan yang ada. Jumlah persediaan yang tidak sesuai mengakibatkan perhitungan harga pokok makanan menjadi tidak sesuai dengan persediaan yang ada. Pencatatan yang tidak teratur ini juga mengakibatkan ketidaksesuaian pencatatan jurnal harga pokok makanan yang dilakukan oleh bagian keuangan.

Terdapat penelitian terdahulu mengenai pembuatan aplikasi. Pengelolaan persediaan meliputi pembelian bahan baku, pengelolaan persediaan barang jadi dan penjualan persediaan. Pencatatan persediaan menggunakan metode perpetual dan perhitungan nilai persediaan menggunakan metode FIFO persediaan[2][3][4][5]. Pengelolaan data pembelian bahan baku meliputi pengelolaan data pemasok dan data persediaan bahan baku yang masuk ke gudang[4]. Pengelolaan persediaan bahan baku juga memperhitungkan safety stock bahan baku untuk mengetahui batas jumlah minimal barang yang tersedia[3].

Pengadaan bahan baku untuk diproduksi dapat melalui bagian persediaan dengan melakukan permintaan bahan baku terlebih dahulu[3]. Barang yang telah diproduksi akan dicatat sebagai pemasukan dalam persediaan barang jadi[2]. Pengeluaran bahan baku selain untuk produksi pada pabrik pusat adalah pengeluaran bahan baku untuk setiap gerai[4]. Setiap gerai akan membuat data pemesanan bahan baku kepada bagian gudang pusat[4]. Pengawasan persediaan bahan baku tidak hanya pada gudang pusat namun juga dilakukan pada gudang setiap gerai[4]. Penjualan barang jadi dapat dilakukan secara langsung[2][4] atau melalui distributor[2]. Data penjualan berasal dari nota penjualan[2], faktur penjualan pada distributor[3] dan daftar penjualan pada setiap gerai[4]. Perhitungan nilai penggunaan persediaan bahan baku dapat menghasilkan nilai biaya bahan baku. Perhitungan nilai barang yang terjual menghasilkan total barang yang terjual. Biaya bahan baku dan total barang yang terjual merupakan komponen dalam perhitungan harga pokok penjualan[4]. Informasi yang dihasilkan oleh aplikasi persediaan berupa jurnal, buku besar, kartu persediaan[2] [3][4] dan laporan penjualan[2][3].

Penelitian sebelumnya dapat dikembangkan pada pemanfaatan data harga pokok makanan. Berdasarkan kendala yang terjadi pada obyek penelitian, maka dibangun aplikasi yang mampu mengelola pencatatan transaksi pembelian, penyerahan, pengambilan dan penyesuaian fisik persediaan bahan makanan, mampu memantau dan memberi informasi jumlah persediaan bahan makanan pada setiap tempat penyimpanan. Aplikasi yang dibangun juga mampu mengelola transaksi pembelian, penyerahan, pengambilan dan penyesuaian fisik bahan makanan. Aplikasi yang dibangun dapat membantu bagian pembelian mengawasi persediaan bahan makanan pada tempat penyimpanan bagian pembelian dan tepat penyimpanan bagian dapur. Pengawasan persediaan pada aplikasi berupa daftar persediaan pada setiap tempat penyimpanan. Aplikasi yang dibangun dapat melakukan penilaian persediaan menggunakan metode FIFO dan menghitung harga pokok 
makanan. Aplikasi yang dibangun juga dapat menghasilkan jurnal, buku besar dan laporan harga pokok makanan.

\section{Kerangka Teoritis}

\section{Persediaan bahan makanan}

Persediaan adalah aktiva lancar yang tersedia untuk dijual atau digunakan dalam proses produksi atau pemberian jasa. Menurut IAS No. 2 Inventory dan PSAK No. 14 Persediaan, persediaan adalah aktiva lancar yang tersedia untuk diproses produksi, dijual kembali maupun digunakan dalam pemberian jasa[6]. Persediaan dapat diklasifikasikan berdasarkan jenis perusahaanya. Persediaan pada perusahaan dagang adalah persediaan barang dagang sedangkan persediaan pada perusahaan manufaktur terdapat tiga kelompok persediaan yaitu persediaan bahan baku, persediaan barang dalam proses dan persediaan barang jadi. Usaha restoran termasuk jenis perusahaan dagang. Pada usaha restoran terdapat persediaan berupa persediaan bahan makanan, persediaan minuman dan perlengkapan[7]. Persediaan bahan makanan merupakan persediaan berupa bahan makanan yang terdapat pada gudang makanan dan dapur[8]. Persediaan bahan makanan terbagi menjadi tiga jenis, yaitu: bahan makanan segar seperti sayur, buah, daging dan makanan laut (seafood); bahan makanan yang dapat disimpan lebih lama seperti kopi, gula, tepung, beras, saus botol dan makanan dalam kaleng; dan bahan makanan yang dibekukan (frozen foods) [9].

Salah satu metode pencatatan persediaan dalam akuntansi adalah metode perpetual. Pencatatan persediaan dengan metode perpetual dilakukan setiap terjadi transaksi yang berhubungan dengan persediaan[6]. Saat terjadi transaksi pembelian, akun yang digunakan pada metode perpetual adalah akun persediaan bahan makanan. Pada metode perpetual akun pembelian diganti dengan akun harga pokok makanan. Pencatatan persediaan metode perpetual dibantu dengan kartu persediaan. Keuntungan penggunaan metode perpetual adalah perusahaan dapat mengetahui jumlah masuk dan keluar persediaan dan dapat langsung mengetahui jumlah persediaan yang tersedia saat ini. Persediaan yang dicatat akan dihitung nilainya. Tabel 1, tabel 2, tabel 3 dan tabel 4 adalah pencatatan jurnal menggunakan metode perpetual.

a. Pencatatan transaksi pembelian secara tunai

Tabel 1. Jurnal Pembelian Tunai Metode Perpetual

\begin{tabular}{|c|c|c|c|}
\hline Tanggal & Akun & Debit & Kredit \\
\hline $01 / 10 / 2016$ & Persediaan Bahan Makanan & Rp 5.000.000,- & \\
\hline & Kas & & Rp 5.000.000,- \\
\hline
\end{tabular}

b. Pencatatan transaksi pemakaian bahan makanan

Tabel 2. Jurnal Pemakaian Baban Makanan

\begin{tabular}{|c|c|c|c|}
\hline Tanggal & Akun & Debit & Kredit \\
\hline $05 / 10 / 2016$ & Harga Pokok Makanan & Rp 11.000.000,- & \\
\hline & Persediaan Bahan Makanan & & Rp 11.000.000,- \\
\hline
\end{tabular}

c. Pencatatan selisih kekurangan persediaan bahan makanan

Tabel 3. Jurnal Selisib Kekurangan Persediaan Bahan Makanan 


\begin{tabular}{|c|c|c|c|}
\hline Tanggal & Akun & Debit & Kredit \\
\hline $30 / 10 / 2016$ & Harga Pokok Makanan & Rp 2.000.000,-- & \\
\hline & Persediaan Bahan Makanan & & Rp 2.000.000, \\
\hline
\end{tabular}

d. Pencatatan selisih kelebihan persediaan bahan makanan

Tabel 4. Jurnal Selisih Kelebihan Persediaan Bahan Makanan

\begin{tabular}{|c|c|c|c|}
\hline Tanggal & Akun & Debit & Kredit \\
\hline $30 / 10 / 2016$ & Persediaan Bahan Makanan & $\mathrm{Rp} 2.000 .000,-$ & \\
\hline & Harga Pokok Makanan & & $\mathrm{Rp} 2.000 .000,-$ \\
\hline
\end{tabular}

Metode First In First Out (FIFO) adalah salah satu metode perhitungan nilai persediaan[6]. Metode FIFO mengasumsikan nilai barang yang dikeluarkan adalah nilai barang yang masuk pertama[10]. Keuntungan menggunakan metode FIFO adalah harga perolehan barang yang dihasilkan menggunakan harga beli dari barang itu sendiri. Tabel 5 adalah bentuk kartu persediaan menggunakan metode FIFO.

Tabel 5 Kartu Persediaan Metode FIFO

\begin{tabular}{|c|c|c|c|c|c|c|c|c|c|}
\hline \multicolumn{10}{|c|}{ KARTU PERSEDIAAN } \\
\hline \multicolumn{10}{|c|}{ Periode Juni 2013} \\
\hline \multicolumn{10}{|c|}{ Metode : FIFO } \\
\hline & \multicolumn{3}{|c|}{ Masuk / Beli } & \multicolumn{3}{|c|}{ Keluar / Jual } & \multicolumn{3}{|c|}{ Saldo } \\
\hline Tanggal & Q & Harga & Total & Q & Harga & Total & $\mathrm{Q}$ & Harga & Total \\
\hline $01 / 06 / 2013$ & & & & & & & 7 & Rp9.000 & Rp63.000 \\
\hline $05 / 06 / 2013$ & 10 & Rp10.000 & Rp100.000 & & & & 10 & Rp10.000 & Rp100.000 \\
\hline $12 / 06 / 2013$ & & & & 7 & Rp9.000 & Rp63.000 & 0 & $\mathrm{Rp} 0$ & $\mathrm{Rp} 0$ \\
\hline & & & & 5 & Rp10.000 & Rp50.000 & 5 & Rp10.000 & Rp50.000 \\
\hline & & & & & & & 5 & Rp10.000 & Rp50.000 \\
\hline $13 / 06 / 2013$ & 20 & Rp12.000 & Rp240.000 & & & & 20 & Rp12.000 & Rp240.000 \\
\hline $20 / 06 / 2013$ & & & & 5 & Rp10.000 & Rp50.000 & 0 & $\mathrm{Rp} 0$ & $\mathrm{Rp} 0$ \\
\hline & & & & 5 & Rp12.000 & Rp60.000 & 15 & Rp12.000 & Rp180.000 \\
\hline Total Masuk & 30 & & Rp340.000 & & & & & & \\
\hline Total Keluar & & & & 22 & & Rp223.000 & & & \\
\hline Saldo Akhir & & & & & & & 15 & Rp12.000 & Rp180.000 \\
\hline
\end{tabular}

Pada kartu persediaan dapat diketahui nilai persediaan yang masih ada. Pada kartu persediaan juga dapat langsung diketahui nilai harga pokok makanan[9]. Pada tabel 5 kartu persediaan diketahui nilai harga pokok makanan pada periode Juni 2013 adalah Rp 223.000,--

\section{Harga Pokok Makanan}

Seluruh bahan makanan yang digunakan dalam pembuatan makanan disebut harga pokok makanan[7]. Perhitungan harga pokok makanan berbeda dengan harga pokok produksi pada perusahaan manufaktur yang memproduksi makanan[9]. Komponen perhitungan harga pokok produksi melibatkan biaya bahan baku, biaya tenaga kerja langsung dan biaya overhead. Komponen perhitungan harga pokok makanan hanya melibatkan biaya penggunaan bahan makanan saja[9]. Perhitungan harga pokok makanan tidak melibatkan biaya tenaga kerja dan biaya overhead. Biaya 
tenaga kerja dan biaya overhead pada usaha hotel dan restoran merupakan biaya yang dibebankan pada setiap departemen.

Semua bahan makanan yang dikeluarkan pada perhitungan persediaan merupakan harga pokok makanan yang dikonsumsi[9]. Nilai harga pokok makanan yang dikonsumsi belum menunjukan harga pokok makanan yang dijual. Nilai pada harga pokok makanan yang dikonsumsi masih mengandung nilai pemakaian bahan makanan di luar kegiatan penjualan makanan[1]. Pemakaian bahan makanan diluar penjualan meliputi pemakaian untuk makan pegawai, pengambilan bahan makanan oleh bagian dapur, pemakaian untuk kegiatan rapat dan promosi. Harga pokok makanan dijual merupakan harga pokok makanan yang dikonsumsi dikurangi dengan jumlah pemakaian bahan makanan di luar kegiatan penjualan[9]. Contoh laporan harga pokok makanan dapat dilihat pada Gambar 1.

\begin{tabular}{|c|c|c|c|c|}
\hline \multicolumn{5}{|c|}{$\begin{array}{c}\text { Restoran Ramora } \\
\text { Laporan Harga Pokok Makanan } \\
\text { Per } 30 \text { Juni } 2013\end{array}$} \\
\hline \multicolumn{5}{|c|}{ Bahan makanan yang digunakan: } \\
\hline 1. Cabe Merah & $=70 \mathrm{Kg} \times \mathrm{Rp} 11.000$ & $=\mathrm{Rp} 770.000$ & & \\
\hline 2. Bihun & $=30 \mathrm{Kg} \times \mathrm{Rp} 5.000$ & $=\operatorname{Rp} 150.000$ & & \\
\hline 3. Melon & $=30 \mathrm{Kg} \times \mathrm{Rp} 12.000$ & $=\operatorname{Rp} 350.000$ & & \\
\hline 4. Mangga & $=40 \mathrm{Kg} \times \mathrm{Rp} 13.000$ & $=\mathrm{Rp} 520.000$ & & \\
\hline Harga Pokok Maka & yang dikonsumsi & & & $=\mathrm{Rp} 1.790 .000$ \\
\hline \multicolumn{5}{|c|}{ Penggunaan Bahan Makanan di luar penjualan } \\
\hline \multicolumn{5}{|c|}{ Penggunaan Bahan Makanan Untuk Karyawan : } \\
\hline 1. Cabe Merah & $=10 \mathrm{Kg} \times \mathrm{Rp} 11.000$ & $=\operatorname{Rp} 110.000$ & & \\
\hline 2. Bihun & $=5 \mathrm{Kg} \times \mathrm{Rp} 5.000$ & $=\operatorname{Rp} 25.000$ & & \\
\hline Total penggunaan & han makanan untuk karyawan & & $=\mathrm{Rp} 135.000$ & \\
\hline \multicolumn{5}{|c|}{ Penggunaan Bahan Makanan Oleh Bagian Bar: } \\
\hline 1. Melon & $=20 \mathrm{Kg} \times \mathrm{Rp} 12.000$ & $=\operatorname{Rp} 240.000$ & & \\
\hline 2. Mangga & $=12 \mathrm{Kg} \times \mathrm{Rp} 13.000$ & $=\operatorname{Rp} 156.000$ & & \\
\hline \multicolumn{3}{|c|}{ Total penggunaan bahan makanan oleh bagian bar } & $=\mathrm{Rp} 396.000$ & \\
\hline \multicolumn{4}{|c|}{ Total penggunaan bahan makanan di luar penjualan } & $=(\operatorname{Rp} 531.000)$ \\
\hline \multicolumn{3}{|c|}{ Harga Pokok Makanan yang dijual } & & $=\operatorname{Rp} 1.259 .000$ \\
\hline
\end{tabular}

Gambar 1. Laporan Harga Pokok Makanan

\section{Analisis dan Desain Berbasis Obyek menggunakan Unified Modeling Language (UML)}

Unified Modeling Language (UML) merupakan bahasa pemodelan untuk pembangunan perangkat lunak berorientasi objek[11]. Pemodelan UML menggunakan empat diagram yaitu use case diagram, diagram kelas, diagram aktivitas dan diagram sekuen.

\section{Pembangunan Aplikasi Berbasis Web Framework}

Pembuatan suatu aplikasi berbasis web berorientasi objek menggunakan PHP Framework, yaitu CodeIgniter (CI). CodeIgniter (CI) merupakan kerangka kerja atau framework pembuatan program dengan menggunakan bahasa pemrograman PHP yang lebih sistematis[11]. CodeIgniter (CI) menggunakan metode MVC atau Model View Controller. Metode MVC memisahkan komponen aplikasi berdasarkan komponen utama. Komponen utama pada metode MVC adalah model, view, dan controller. Model berhubungan dengan basis data. Pada model dilakukan manipulasi data seperti memasukan data, mengubah data dan menghapus data menggunakan perintah-perintah SQL. Model tidak dapat menampilkan data secara langsung. Penampilan data dilakukan pada komponen 
view. View merupakan antar muka pengguna yang melayani permintaan dari pengguna. View tidak dapat terhubung secara langsung dengan model. Controller merupakan penghubung antara model dan view. Controller berisi fungsi-fungsi yang memproses permintaan dari view ke dalam struktur data pada model[11].

Sistem manajemen basis data merupakan sistem yang dapat mengelola data pada suatu aplikasi[12]. Mengelola data artinya kemampuan menyimpan data, menampilkan data dan melakukan integrasi antar data. Pengelolaan basis data dapat menggunakan bahasa query yaitu Structred Query Language (SQL). Salah satu sistem manajemen basis data open source yang sering digunakan adalah MySQL. MySQL mempunyai tipe data yang lengkap seperti date, integer, varchar, time, dan text. Tabel data pada MySQL sangat fleksibel sehingga mudah ditangani jika terjadi kesalahan pada tabel[12].

\section{Metode}

Pengumpulan data dilakukan dengan cara melakukan wawancara dan obervasi ke Kongkalikong Dine and Cafe. Wawancara dilakukan kepada kepala bagian pembelian dan kepala bagian dapur Kongkalikong Dine and Cafe. Observasi dilakukan dengan mengamati sendiri proses binis mengenai persediaan pada Kongkalikong Dine and Cafe. Selain melakukan wawancara dan observasi, pengumpulan data juga dilakukan dengan cara mencari informasi melalui buku.

Analisis dan desain berbasis obyek menggunakan Unified Modeling Language (UML). Pemodelan UML yang digunakan adalah use case diagram. Pemodelan data menggunakan Entity Relationship Diagram (ERD). Implementasi dari analisis dan desain berbentuk aplikasi berbasis web yang dibangun menggunakan web framework. CodeIgniter dan basis data MySQL.

\section{Hasil Dan Pembahasan}

\section{Analisis Kebutuhan Pengguna}

Analisis kebutuhan pengguna difokuskan pada identifikasi aliran dokumen, dalam Gambar 2, yang dimulai dari bukti transaksi berupa nota pembelian, dokumen penyerahan bahan baku, dokumen pengambilan bahan baku dan selisih lebih persediaan akhir. Bukti transaksi dicatat dalam bentuk jurnal dan dikelompokkan sesuai akun pada buku besar[6]. Pencatatan persediaan dilakukan berdasarkan bukti transaksi atas setiap terjadi transaksi pembelian dan pemakaian bahan makanan, sehingga nilai persediaan bahan makan dapat diketahui setiap saat, sehingga metode pencatatan persediaan yang tepat digunakan adalah metode perpetual. Kartu persediaan menampilkan perhitungkan nilai persediaan dengan metode First In First Out (FIFO) untuk memperlihatkan harga perolehan barang yang sesungguhnya[10]. Manager membutuhkan informasi keseluruhan bahan makanan yang digunakan dalam pembuatan makanan ditampilkan dalam bentuk laporan harga pokok makanan[7]. 
Gabriella Dwi Ayuni, Magdalena Karismariyanti

Aplikasi Berbasis Web

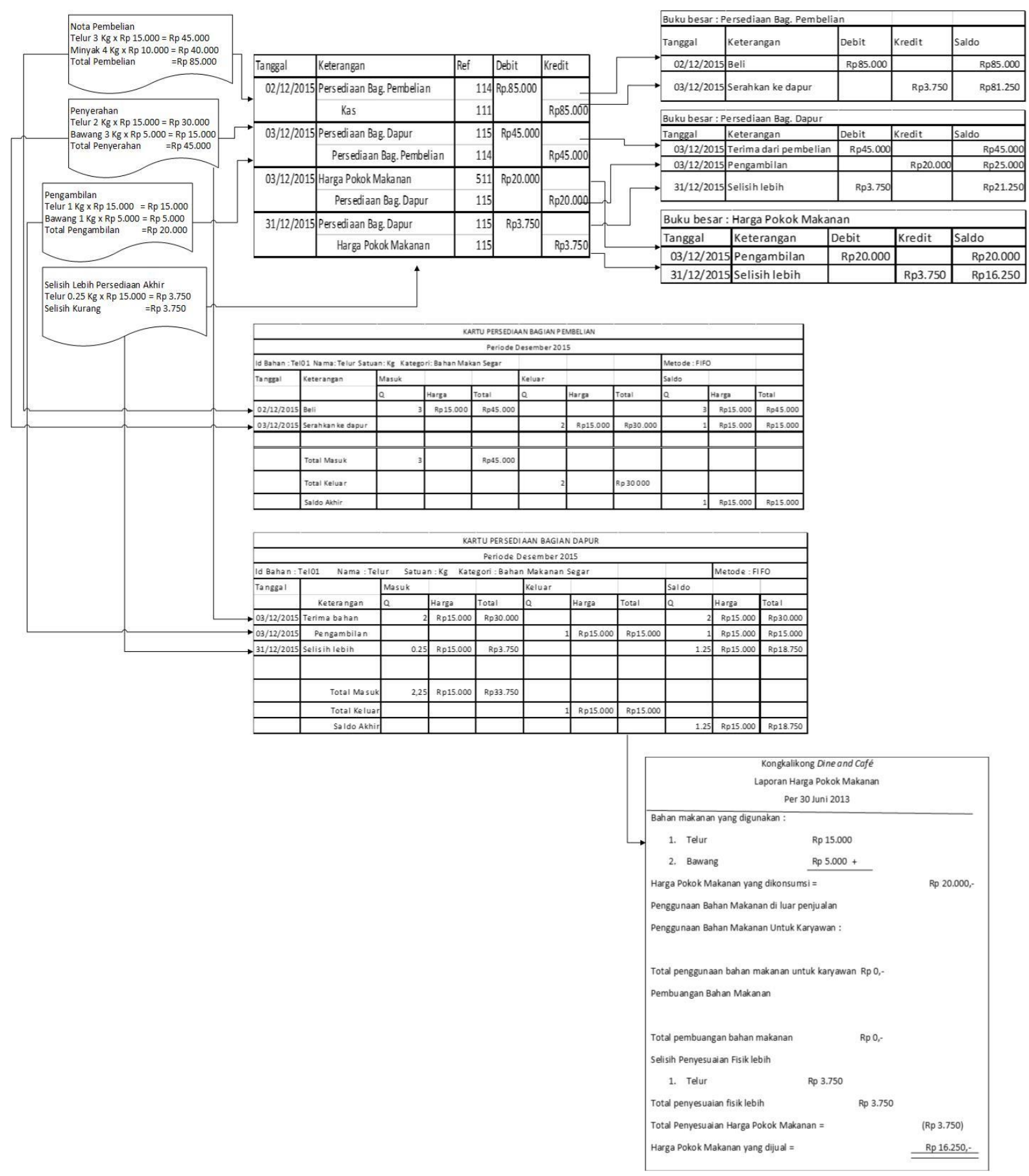

Gambar 2. Aliran Dokumen

\section{Use Case Diagram}

Analisis sistem dimodelkan dengan Use Case Diagram. Use case menggambarkan interaksi aktor dengan fungsionalitas (atau use case) sistem[11]. Dalam tahap analisis, terdapat empat (4) orang/proses yang bertukar pesan dengan sistem, yaitu: Bagian Dapur, Bagian Pembelian, Bagian Keuangan, dan Manager. Use case menjelaskan fungsionalitas yang ada pada sistem berjumlah 39. Gambar 3 memperlihatkan aktor yang menjalankan fungsionalitas masing-masing. 
Gabriella Dwi Ayuni, Magdalena Karismariyanti

Penerapan Penilaian Persediaan Dan Perhitungan

Harga Pokok Makanan Dengan Metode Fifo Pada

Aplikasi Berbasis Web
Jurnal @ is The Best Vol. 04 No. 01. Juni 2019: Hal 381-395

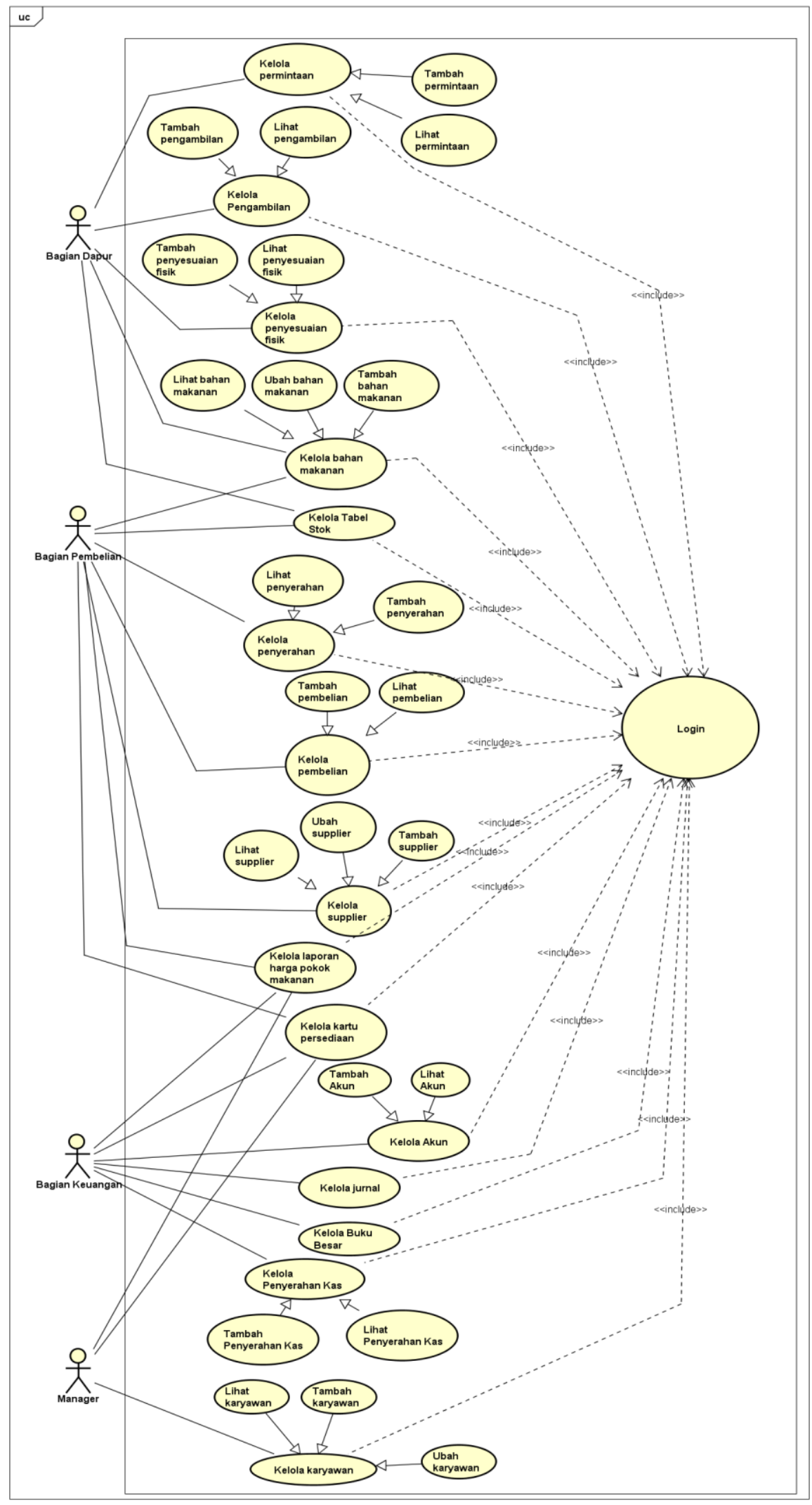

Gambar 3. Use Case Diagram 


\section{Diagram Relasi Entitas}

Relasi antar entitas pada sistem digambarkan dengan diagram relasi entitas atau Entity Relationship Diagram (ERD)[13]. Notasi ERD yang digunakan pada penelitian ini adalah notasi ERD yang dikembangkan oleh Peter Chen[11]. Gambar 4 menampilkan 11 entitas kuat, dan 6 relasi binary dengan kadinalitas many-to-many, dengan proyeksi tabel yang akan dihasilkan berjumlah 17 tabel.

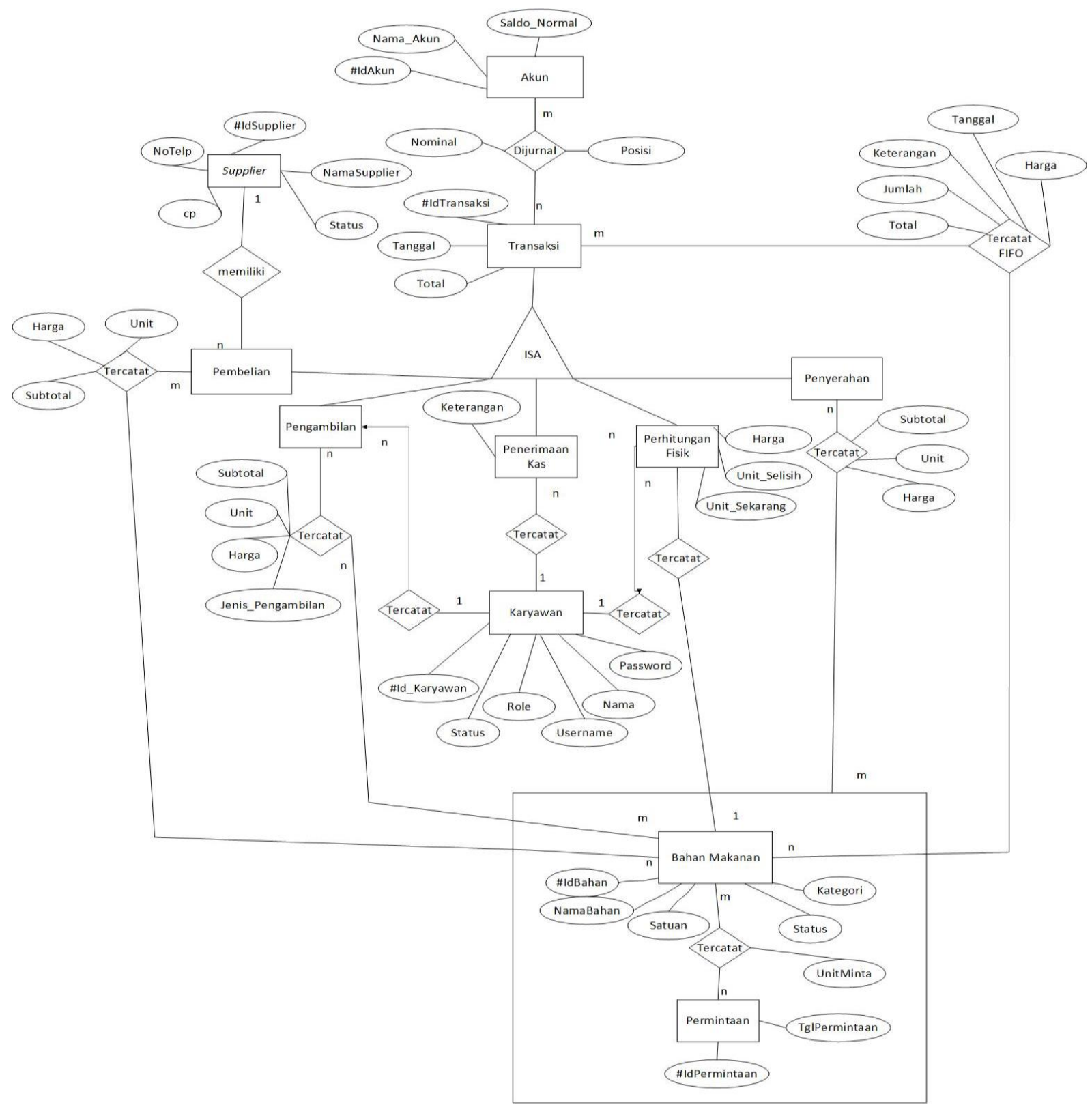

Gambar 4. Entity Relationship Diagram (ERD) 


\section{Implementasi}

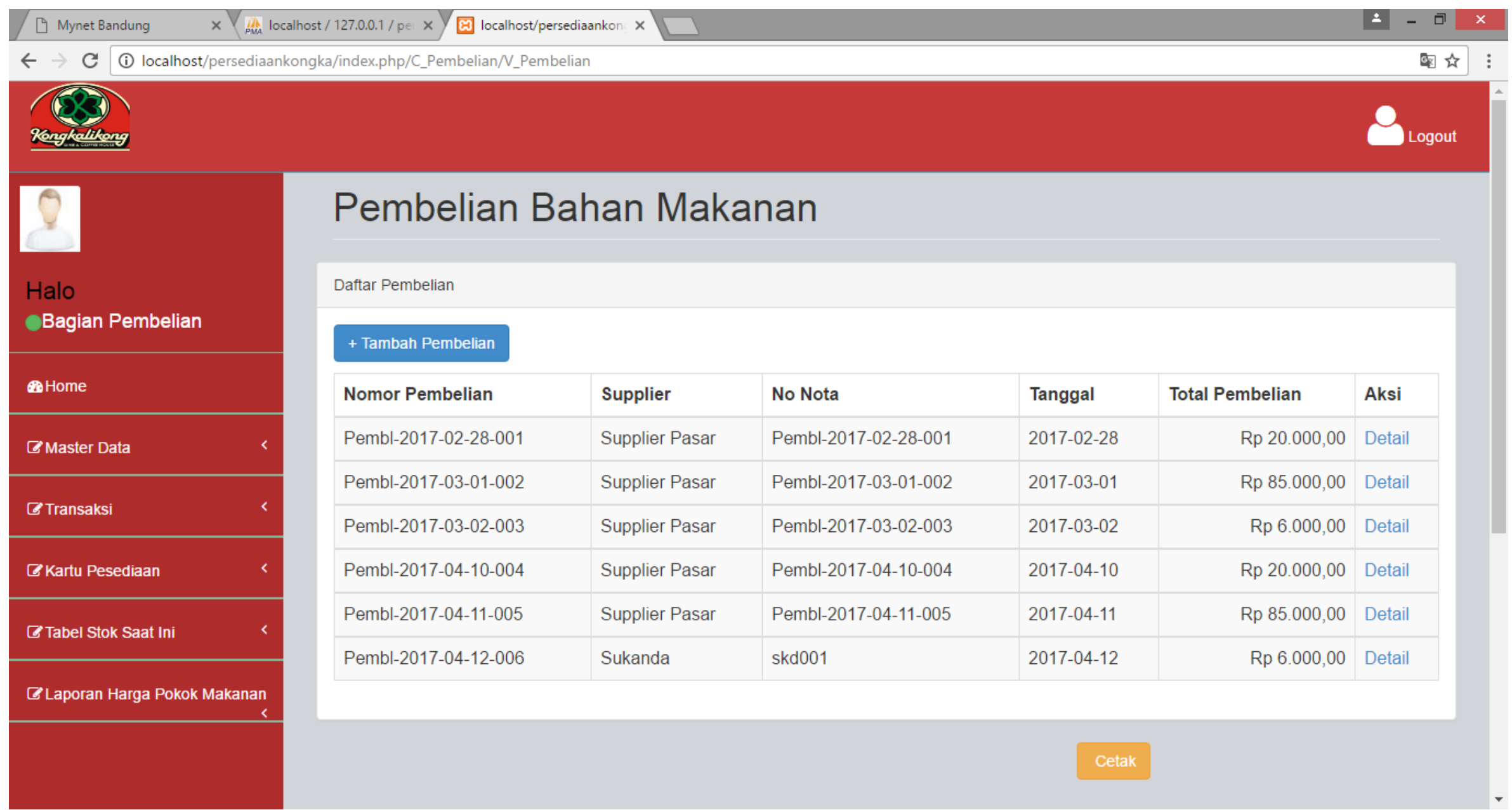

\section{Gambar 5. Implementasi Halaman Pembelitan Bahan Makanan}

Aktor bagian pembelian dari use case Lihat Pembelian, diimplementasikan pada Gambar 5. Data yang ditambahkan pada halaman Pembelian Bahan Makanan disimpan ke tabel pembelian dan detail_pembelian sesuai dengan ERD. Jurnal yang dihasilkan adalah Persediaan Bag.Pembelian pada Kas. 


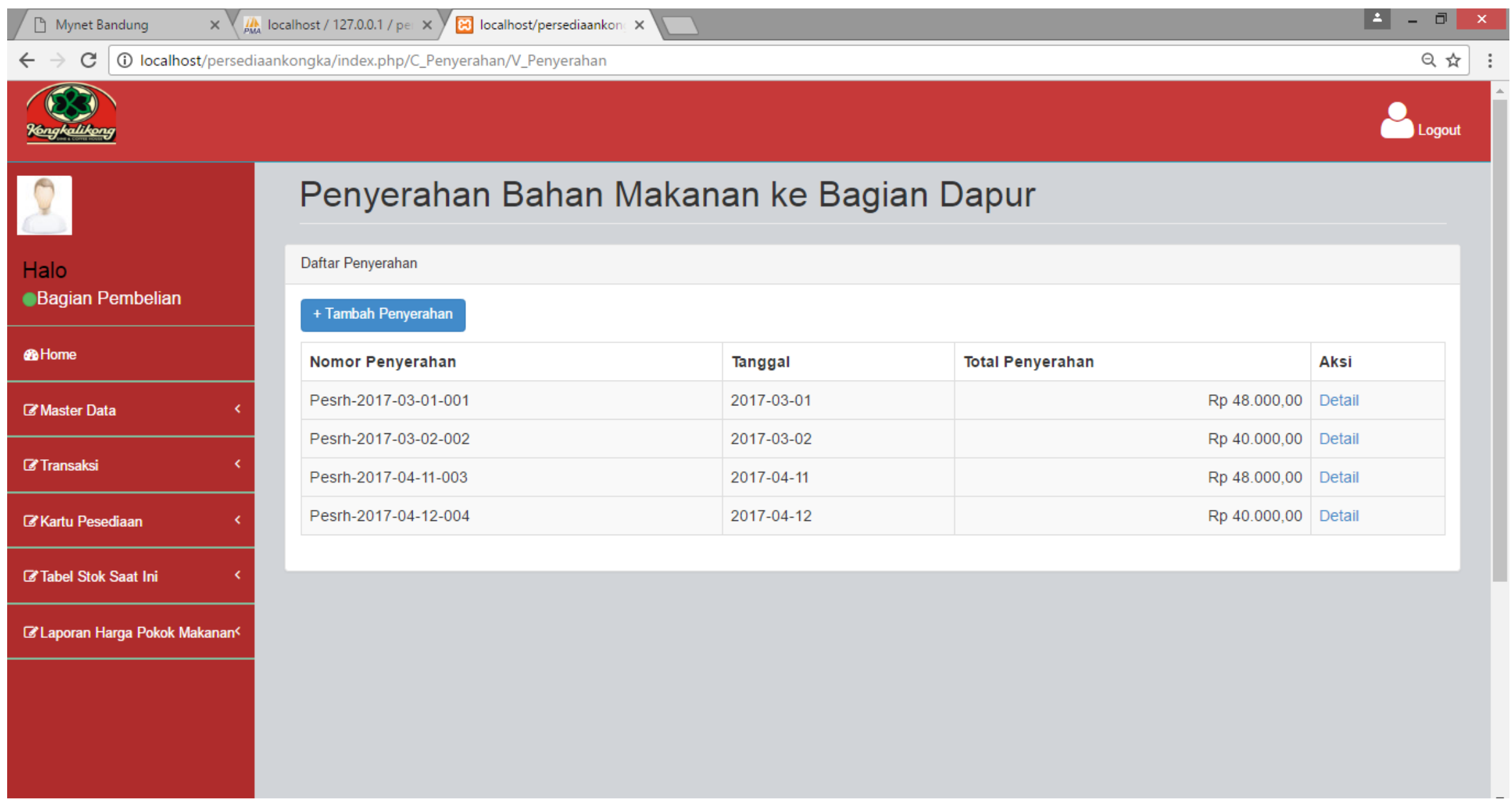

Gambar 6. Implementasi Halaman Penyerahan Bahan Makanan ke Bagian Dapur 
Gabriella Dwi Ayuni, Magdalena Karismariyanti

Penerapan Penilaian Persediaan Dan Perhitungan

Harga Pokok Makanan Dengan Metode Fifo Pada

Aplikasi Berbasis Web
Jurnal @ is The Best

Vol. 04 No. 01. Juni 2019: Hal 381-395

Aktor bagian pembelian menyerahkan bahan baku dari gudang pembelian ke Gudang dapur dengan implementasi halaman Penyerahan Bahan Makanan ke Bagian Dapur pada Gambar 6. Secara akuntansi transaksi tersebut akan dicatat pada akun Persediaan Bag.Dapur pada sisi debit dan Persediaan Bag.Pembelian pada sisi kredit. Input Pengambilan Bahan Makanan

Tanggal
2017-05-11
Nomor Pengambilan
Pambl-2017-05-11-009
Karyawan
(Krywn-002) Bowo
Jenis Pengambilan
Pemakaian Bahan
Total (Rp)
17500

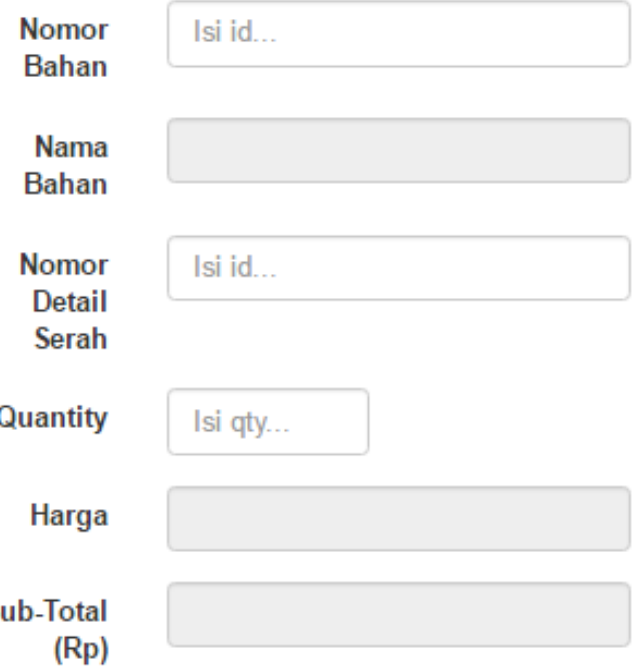

Tambah

\begin{tabular}{|l|l|l|r|r|r|r|}
\hline No & Nomor Bahan & Nama Bahan & Quantity & Harga & Substotal \\
\hline 1 & BMkan-001 & Abon Sapi & 0.5 & Rp. 11,000.00 & Rp. 5,500.00 & Hapus Barang \\
\hline 2 & BMkan-004 & Sambal Bajak & 1 & Rp. 12,000.00 & Rp. 12,000.00 Hapus Barang & Hap \\
\hline
\end{tabular}




\section{Gambar 7. Implementasi Halaman Input Pengambilan Bahan Makanan}

Use case Tambah Pengambilan sesuai Gambar 3 pada Input Pengambilan Bahan Makanan (Gambar 7) adalah proses yang dilakukan aktor dengan hak akses bagian dapur untuk memasukan data bahan makanan yang akan diambil untuk digunakan dalam pembuatan masakan. Proses ini mencatat akun Harga Pokok Makanan pada akun Persediaan Bag.Dapur.

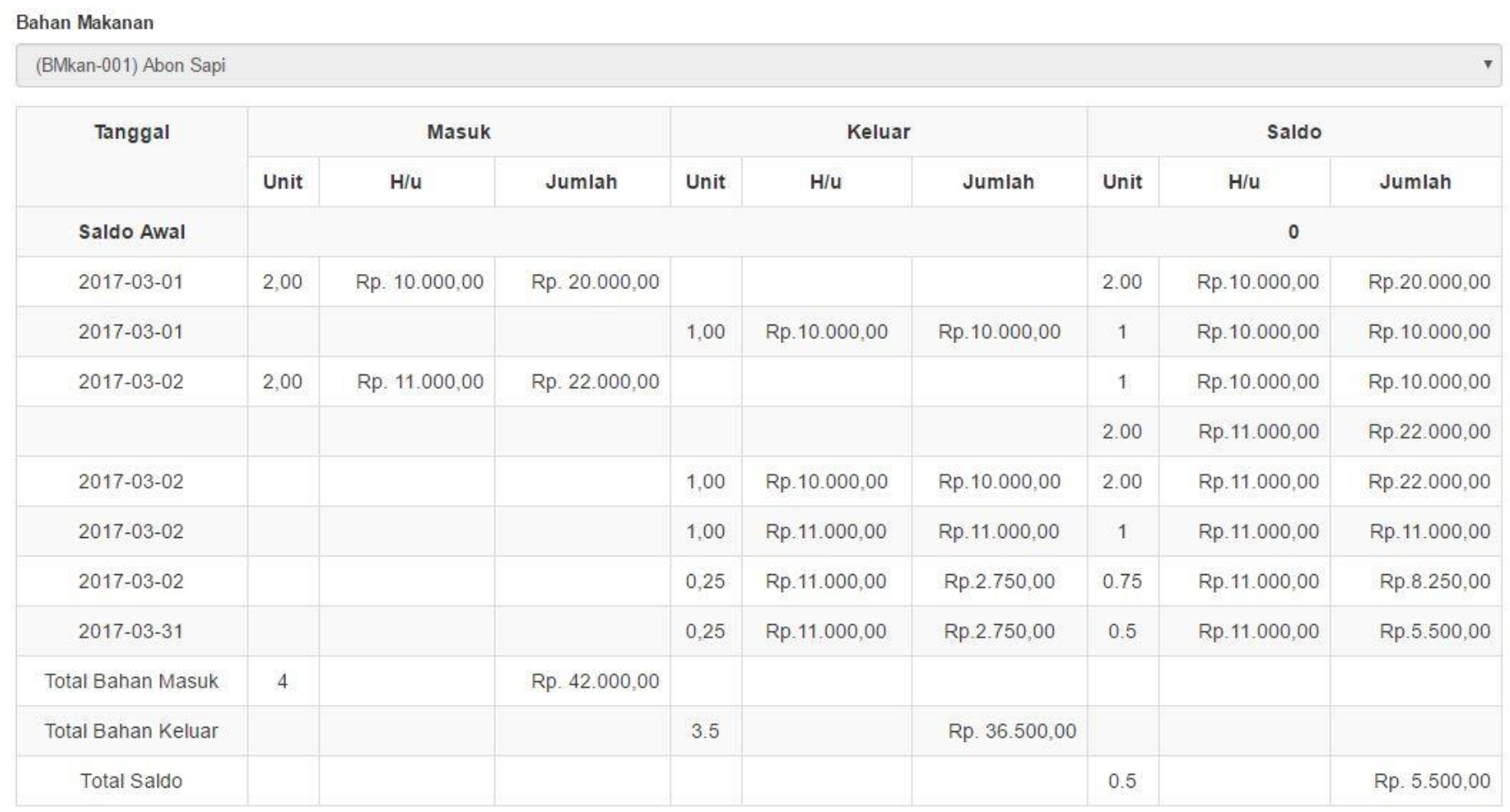

Gambar 8. Implementasi Halaman Kartu Persediaan Bagian Dapur

Aplikasi menampilkan Kartu Persediaan Bagian Dapur untuk bahan makanan Abon Sapi (Gambar 8), menggunakan metode perpetual FIFO. Bahan makanan masuk ke bagian dapur dicatat berdasarkan proses Penyerahan Bahan Makanan ke Bagian Dapur pada Gambar 6, sedangkan bahan 
Aplikasi Berbasis Web

baku dicatat sebagai keluar atas proses Input Pengambilan Bahan Makanan pada Gambar 7. Pada Gambar 8 kartu persediaan diketahui nilai harga pokok makanan Abon Sapi adalah Rp 36.500, yang akan digunakan pada Gambar 9 pada Harga Pokok Makanan (BMkan-001) Abon Sapi dengan jumlah yang sama.

Perhitungan harga pokok makanan yang dijual dapat dilakukan berdasarkan total bahan makanan keluar pada setiap Kartu Persediaan Bagian Dapur, transaksi pengambilan bahan makanan untuk makanan pegawai, transaksi pengambilan bahan makanan untuk dibuang dan transaksi penyesuaian fisik lebih bahan makanan bagian dapur. Gambar 9 menampilkan perhitungan harga pokok makanan yang dijual.

\begin{tabular}{|c|c|c|}
\hline (283) & $\begin{array}{c}\text { Kongkalikong Cafe } \\
\text { Laporan Harga Pokok Makanan } \\
\text { Per 2017-02-28 / 2017-03-31 }\end{array}$ & \\
\hline \multicolumn{3}{|l|}{ Harga Pokok Makanan } \\
\hline (BMkan-001) Abon Sapi & Rp 36.500 & \\
\hline (BMkan-004) Sambal Bajak & Rp 30.000 & \\
\hline (BMkan-006) Bayam & Rp 10.000 & \\
\hline \multicolumn{2}{|l|}{ Total Harga Pokok Makanan } & Rp. 76.500 \\
\hline \multicolumn{3}{|l|}{ Beban Makan Pegawai } \\
\hline $\begin{array}{l}\text { (BMkan-001) Abon Sapi } \\
\text { (BMkan-004) Sambal Bajak }\end{array}$ & $\begin{array}{l}\operatorname{Rp} 11.000 \\
\operatorname{Rp} 6.000\end{array}$ & \\
\hline \multicolumn{2}{|l|}{ Total Beban Makan Pegawai } & (Rp. 17.000) \\
\hline \multicolumn{3}{|l|}{ Beban Kerugian Bahan Terbuang } \\
\hline (BMkan-001) Abon Sapi & $\operatorname{Rp} 2.750$ & \\
\hline \multicolumn{2}{|l|}{ Total Bahan Makanan Terbuang } & (Rp. 2.750 ) \\
\hline \multicolumn{3}{|l|}{ Penyesuaian Fisik Bahan (Lebih) } \\
\hline (BMkan-004) Sambal Bajak & Rp 6.000 & \\
\hline \multicolumn{2}{|l|}{ Total Selisih Perhitungan Fisik } & (Rp. 6.000) \\
\hline \multicolumn{2}{|c|}{ Harga Pokok Makanan yang Dijual } & Rp. 50.750 \\
\hline
\end{tabular}

Gambar 9. Laporan harga pokok makanan pada aplikasi

Metode FIFO menghasilkan harga perolehan barang yang sesungguhnya karena nilai barang yang digunakan merupakan nilai dari barang itu sendiri. Nilai yang ditampilkan dalam kartu persediaan secara langsung menjadi nilai pada Harga Pokok Makanan. Metode pencatatan persediaan perpetual dilakukan setiap kali terjadi transaksi yang berhubungan dengan persediaan, sehingga secara aplikasi dapat mengimplementasi What You See Is What You Get (WYSIWYG). Pencatatan transaksi pembelian bahan makanan tidak menggunakan akun pembelian namun langsung menggunakan 
Gabriella Dwi Ayuni, Magdalena Karismariyanti

Penerapan Penilaian Persediaan Dan Perhitungan

Harga Pokok Makanan Dengan Metode Fifo Pada

Aplikasi Berbasis Web

akun persediaan bahan makanan. Pada saat transaksi pemakaian bahan makanan dilakukan jurnal menggunakan akun persediaan bahan makanan dan akun harga pokok makanan. Pada akhir periode tidak dilakukan perhitungan fisik ke gudang dan tidak dilakukan jurnal penyesuaian. Pencatatan dengan metode perpetual dapat membantu perusahaan mengetahui nilai persediaan bahan makanan setiap saat. Kelebihan metode perpetual yaitu nilai persediaan bahan makan dapat diketahui setiap saat karena pencatatan persediaan dilakukan setiap terjadi transaksi pembelian dan pemakaian bahan makanan.
Jurnal @ is The Best

Vol. 04 No. 01. Juni 2019: Hal 381-395 
Penerapan metode perpetual FIFO dapat membantu bagian pembelian mengawasi persediaan bahan makanan pada tempat penyimpanan bagian pembelian dan tepat penyimpanan bagian dapur. Pengawasan persediaan pada aplikasi berupa daftar persediaan pada setiap tempat penyimpanan tersebut. Pengawasan yang akuntabel sesuai dengan bukti transaksi yang terjadi tercatat secara terperinci dari setiap transaksi dan ditampilkan catatan akuntansi berbentuk jurnal dan laporan harga pokok makanan.

\section{Penutup}

Berdasarkan pembahasan maka hasil penelitian berupa aplikasi berbasis web ini mampu menampilkan pencatatan akuntansi yang sesuai dengan standard akuntansi. Aplikasi yang dibangun mampu menangani transaksi pembelian, penyerahan, pengambilan dan penyesuaian fisik bahan makanan. Bagi pengembangan penelitian ini, disarankan untuk menambah fungsionalitas berupa optimasi persediaan contohnya menggunakan metode Economic Order Quantity (EOQ)[14] dan menambahkan fungsionalitas berupa konversi satuan bahan makanan secara otomatis.

\section{Daftar Pustaka}

[1] J. J. Weygandt, D. E. Kieso, A. L. DeFranco, and P. D. Kimmel, Hospitality Financial Accounting. New Jersey: Wiley, 2008.

[2] P. N. Anggraini, A. A. Agung, and H. Zulhaimi, "Aplikasi Pencatatan Persediaan Tahu dengan Metode FIFO Berbasis Web (Studi Kasus : CV Barka Mazaya)." Universitas Telkom, Bandung, 2014.

[3] C. Anis, Kusnadi and H. Zulhaimi, "Aplikasi Pengelolaan Persediaan dengan Metode Perpetual dan Penilaian FIFO (Studi Kasus di PT. Muawanah Al-Ma'soem)." Universitas Telkom, Bandung, 2014.

[4] N. Suryadi and I. Yuniar, "Aplikasi Persediaan dan Perhitungan Harga Pokok Penjualan Bahan Baku Berbasis Web (Studi Kasus : Donat Madu, Cimahi).” Universitas Telkom, Bandung, 2014.

[5] C. Dwiprastio, M. Karismariyanti, and R. Sukawati, "Aplikasi Penjualan dan Persediaan Barang Dagang dengan Metode Perpetual FIFO Berbasis Web (Studi Kasus pada PD. XYZ)," J. Teknol. Inf., vol. 1, no. 3, pp. 82-87, 2012.

[6] H. Kartika, R. U. Sinaga, M. Syamsul, and S. V. Siregar, Akuntansi Keuangan Berdasarkan SAK Berbasis IFRS. Jakarta: Salemba Empat, 2012.

[7] C. Guilding, Accounting Essentials For Hospitality Managers, 3rd ed. New York: Routledge, 2014.

[8] L. R. Dopson and D. K. Hayes, Food \& Beverage Cost Control, 6th ed. Hoboken, New Jersey: John Wiley \& Sons.Inc, 2016.

[9] I. B. Wiyasha, Akuntansi Manajemen Untuk Hotel dan Restoran, Edisi 2. Yogyakarta: ANDI, 2014.

[10] Hery, Teori Akuntansi Suatu Pengantar. Jakarta: Lembaga Penerbit Fakultas Ekonomi Universitas Indonesia, 2013.

[11] R. A. Sukamto and M. Shalahuddin, Rekayasa Perangkat Lunak Terstruktur Dan Berorientasi Objek. Bandung: Informatika, 2013.

[12] K. Darmayuda, Aplikasi Basis Data dengan Visual Basic .NET. Bandung: Informatika, 2014.

[13] J. A. Hall, Accounting Information Systems, 9th ed. Boston: Cengage Learning, 2016.

[14] R. Abdurrofi and M. Karismariyanti, "Aplikasi Untuk Optimasi Persediaan Bahan Baku Menggunakan Model Economic Order Quantity (EOQ) Pada Pabrik Tahu di Jawa Barat," Semnasteknomedia, vol. 4, no. 1, 2016. 